\title{
Protein AF-9
}

National Cancer Institute

\section{Source}

National Cancer Institute. Protein AF-9. NCI Thesaurus. Code C33945.

Protein AF-9 (568 aa, $\sim 63 \mathrm{kDa}$ ) is encoded by the human MLLT3 gene. This protein may play a role in the regulation of transcription. 